\title{
Population Status and Trend of the Maasai Ostrich in the Mid Kenya-Tanzania Borderland
}

\author{
Moses Makonjio Okello1,2*, John Warui Kiringe1, Lekishon Kenana ${ }^{3}$, Fiesta Warinwa ${ }^{4}$, Hanori Maliti5, \\ Noah Wasilwa Sitati ${ }^{4}$, Erastus Kanga ${ }^{3}$, Samwel Bakari ${ }^{5}$, Stephen Ndambuki ${ }^{3}$, Philip Muruthi, \\ Nathan Gichohi', Edeus Massawes, David Kimutai', Machoke Mwita5, Daniel Muteti ${ }^{3}$
}

${ }^{1}$ SFS Center for Wildlife Management, Nairobi, Kenya

${ }^{2}$ Moi University, Department of Tourism, Eldoret, Kenya

${ }^{3}$ Kenya Wildlife Service, Nairobi, Kenya

${ }^{4}$ African Wildlife Foundation, Nairobi, Kenya

${ }^{5}$ Tanzania Wildlife Research Institute, Arusha, Tanzania

Email: *mokello33@gmail.com

How to cite this paper: Okello, M.M., Kiringe, J.W., Kenana, L., Warinwa, F., Maliti, H., Sitati, N.W., Kanga, E., Bakari, S., Ndambuki, S., Muruthi, P., Gichohi, N., Massawe, E., Kimutai, D., Mwita, M. and Muteti, D. (2016) Population Status and Trend of the Maasai Ostrich in the Mid Kenya-Tanzania Borderland. Natural Resources, 7, 558579.

http://dx.doi.org/10.4236/nr.2016.710047

Received: March 22, 2016

Accepted: October 28, 2016

Published: October 31, 2016

Copyright $\odot 2016$ by authors and Scientific Research Publishing Inc. This work is licensed under the Creative Commons Attribution International License (CC BY 4.0).

http://creativecommons.org/licenses/by/4.0/

\section{Abstract}

The Maasai ostrich (Struthio camelus) is a the largest avian species in East Africa and though it's not considered to be a species of conservation concern, some populations are on the decline and this is attributed to bush meat activities, predation on their eggs illegal consumption by humans, habitat destruction and forage competition with other large wildlife species. Climate change is also emerging to be another major threat due to interference with food availability which in turn interferes with the breeding rhythm. Thus, this study examined the population status, trend and distribution of the Maasai ostrich in the Southern Kenya and Northern Tanzania borderland after the 2007 to 2009 drought. The results showed that the species was found across the entire borderland but the Amboseli region had the highest number and density of Maasai ostrich (726.00 $\pm 100.9 ; 0.08 \pm 0.01$ ostriches per $\left.\mathrm{km}^{2}\right)$, followed by Lake Natron area $\left(330.8 \pm 69.8 ; 0.05 \pm 0.01\right.$ ostriches per $\left.\mathrm{km}^{2}\right)$ and the least was in West Kilimanjaro ( $85.5 \pm 18.0 ; 0.03 \pm 0.01$ ostriches per $\mathrm{km}^{2}$ ). Drought caused a decline in the population of the Maasai ostrich but the Amboseli area experienced the highest decline in density $(-13.44 \pm 12.61)$ compared to other borderland sectors. However, the populations increased in most sectors after the drought, and wet season numbers and densities were higher than the dry season. The highest positive increase in number and density was in Lake Natron area $(+85.65 \pm 91.06)$ followed by West Kilimanjaro $(+68.39 \pm 59.54)$, and the least was in the Magadi area $(+22.26 \pm 32.05)$. There is a need to enhance conservation of avian species like the Maasai ostrich other than just focusing on the charismatic species such as the African elephant and black rhino. We therefore recommend joint collaboration in monitoring all large wildlife populations across the Kenya-Tanzania borderland with a view of under- 
standing their status, trend and best management actions that can enhance their conservation.

\section{Keywords}

Borderland, Kenya, Maasai Ostrich, Population Trend and Status, Tanzania

\section{Introduction}

The Ostrich (Struthio camelus) belongs to a group of birds known as ratites (i.e. flightless birds), and is the only surviving representative of the sub-order Struthiones in the family Struthionidae [1] [2] [3]. It's the largest of the nearly 8600 bird species in the world, and is found widely in most countries of Africa, and its close relatives inhabit many areas in Europe, Asia and Africa as well [1] [4]. Eight species of Ostriches are reported to be extinct, and only four sub-species exist dispersed in the Northern, Eastern, and Southern Savannas of Africa. The Maasai or East African Ostrich (Struthio camelus massaicus) which is the focus of this paper has the smallest range out of the four sub-species living in the African content, and occurs only in Kenya and Tanzania [2] [5]. Although it can be found in diverse habitats (open semi-arid plains, short grass plains and open woodlands), they usually avoid areas with dense woody vegetation cover such as bushes and woodlands [2].

All species of Ostriches are mainly herbivorous and forage on a wide range of plant material including; herbs, shrubs, succulents, grasses, creepers, leaves, seeds and small fruits and flowers [2] [6]. They also feed on animals like lizards, mice, grasshoppers, termites and locusts though in small amounts, and generally tend to select high quality food items. This foraging strategy allows them to accumulate large quantities of subcutaneous fat reserves which cushion them in times of food shortage more so during extremely dry seasons and times of drought [2]. Ecologically, they are well adapted to living in dry environments and survive dehydration of up to $25 \%$ but whenever water is available, they will use it [7] [8]. The bulk of their water is obtained from their food or partly feeding early in the morning especially on hygroscopic plant with high water content [9]. Another water saving strategy is excretion of uric acid carried in mucous [10]. The Maasai ostrich usually spends most of its time solitarily, but formation and splitting of groups occur frequently, and during the breeding season, males are territorial [11] [12]. Females normally form associations which are usually accompanied by males [12].

Kenya and Tanzania, local communities have co-existed with the Maasai ostrich and other biodiversity types for centuries, and this was guided by indigenous knowledge and institutions. Although the species is classified as "Least Concern" under the IUCN Red List [13], they are faced by all manner of threats emanating from humans mainly: habitat fragmentation and loss, egg collection and illegal hunting for bush meat, skins and feathers [13] [14] [15] [16]. 
Various authors (e.g. [12] [13] [17] [18] [19] [20]) indicate that in Africa, illegal hunting, foraging competition and habitat destruction have increasingly impacted negatively on population of ostriches, making them scarce in their former range. These human disturbances affect the population dynamics by altering an individual's investment in anti-predator behavior. Another threat facing the Maasai ostrich is predation on their eggs and live individuals by large mammalian carnivores especially lion Panthera leo and hyena Crocuta crocuta and avian predators e.g. Egyptian vulture Neophron percenopterus [21].

Creation of protected areas in Kenya and Tanzania in the last century was viewed as a milestone in preserving biodiversity and their landscapes in view of the threats they faced from humans. This has seen Kenya set aside explosively for biodiversity [22] [23], while nearly $39.8 \%$ of Tanzania is considered to be protected, out of which partially protected areas (IUCN category $\leq$ IV) cover approximately two third of the area [24]. Nevertheless, wildlife species found in the protected areas including the Maasai ostrich tend to move out into adjoining landscapes occupied by humans who may threaten their survival [22] [23] [25] [26] [27]. In this regard, the Maasai ostrich populations found in the Northern Tanzania and Southern Kenya borderland is living in a rapidly changing region characterized by increase in human population, land use changes, human settlements and infrastructure development. Like in other parts of the world, this presents a huge challenge to their conservation in view of the threats posed by the rate high increase of human population, fragmentation, loss and degradation of their habitats [29].

Another emerging threat in the borderland is climate change which may also impact negatively on the population dynamics of the Maasai ostrich. Ostriches usually breed during the dry season from July to October [2], and there is a tendency to lay eggs at the proper time. This is an evolution strategy which ensures that birds time the breeding season to optimize the clutch size produced. However, in the last couple of decades vegetation phenology (the timing of seasonal activities emergence of leaves and flowers, and timing of breeding) of animal species has been found to have changed, and this ecological situation is as a results of climate change [30] [31]. In turn, this has created a mismatch in the timing of egg laying vis-à-vis food availability in some species of birds [32]. Further, breeding adults, the chicks and juveniles require abundant food supply but with climate change this might not happen and in the long-term interfere with the reproduction rhythm of the Maasai ostrich. Overall, the human induced changes in the Northern Tanzania and Southern Kenya borderland coupled by climatic changes poses a big challenge in the conservation of viable populations of the Maasai ostrich. To this end, this study evaluated the effects of the 2007 to 2009 drought on this species in the borderland, and the findings presents an opportunity of understanding the conservation challenges posed by climate change.

\section{Objectives}

The overall objective of this research was to establish the post drought population size 
and trend of a key game bird (the common ostrich) after the 2009 drought in the Kenya-Tanzania borderland.

The specific objectives were to:

1) Determine the population status and trend of the Maasai ostrich in the KenyaTanzania borderland.

2) Establish changes in numbers and density over time.

3) Assess spatial-temporal distribution of the Maasai ostrich in the Kenya-Tanzania borderland.

4) Make recommendations that will enhance monitoring and conservation of wildlife populations across the Kenya-Tanzania borderland.

\section{Methods and Study Site}

\subsection{The 2007 to 2009 Drought and Its Impacts in Kenya}

According to NOOA [33], drought is a deficiency in precipitation over an extended period, usually a season or more, resulting in a water shortage causing adverse impacts on vegetation, animals, and/or people. It is a normal, recurrent feature of climate that occurs in virtually all climate zones, from very wet to very dry. Drought is a temporary aberration from normal climatic conditions, thus it can vary significantly from one region to another. Drought is different than aridity, which is a permanent feature of climate in regions where low precipitation is the norm, as in a desert.

This large mammal count was done at a time when there were two severe droughts in the Kenya/Tanzania borderland [34]. For the entire country, rainfall fell below the monthly average in 8 months out of 12, or 67 percent of the time in 2008. In 2009, the number of months showing less rainfall than the long-term monthly average increased to 9 or 75 per cent of the time. In 2010, the number of rainfall deficit months decreased to 7.5 months (62 percent of the time); and in the first half of 2011, the number of months rose significantly to 5 out of 7 months (72 percent of the time) [34].

A drought occurred from 2008 to 2011 in Kenya with varying durations and intensities across different regions and affecting many economic sectors. It was more severe in the study area between 2007 and 2009. Generally, from 2008-2011, Kenya experienced a meteorological drought with lower than normal precipitation duration and intensities at various times; an agricultural drought with inadequate soil moisture to meet the needs of various crops in the country; a hydrological drought with deficiencies in the availability of surface and groundwater supplies over periods of time; and a socioeconomic drought with physical water shortages affecting the health, well-being, and quality of life of communities across the country. The overall impact of the 2008-2011 droughts in Kenya is estimated at Ksh 968.6 billion (US\$ 12.1 billion). This includes Ksh 64.4 billion (US\$ 805.6 million) for the destruction of physical and durable assets, and Ksh 904.1 billion (US $\$ 11.3$ billion) for losses in the flows of the economy. The most affected sector was livestock (Ksh 699.3 billion), followed by agriculture (Ksh 121.1 billion). The highest values of per capita damage and losses occurred in provinces where the HDI is lowest. The economic impact of the drought is estimated to have slowed 
down the growth of the country's economy by an average of 2.8 percent per year [33] [34].

\subsection{Study Area}

The study area region is situated in the borderland between Kenya and Tanzania. The area stretched from Amboseli Ecosystem to Namanga in Kenya, and from slopes of Kilimanjaro via Longido plains to Lake Natron in northern Tanzania (Figure 1). The region consists of basement plains, saline plains with fresh water swamps and the volcanic slopes of the Mt. Kilimanjaro. Quaternary volcanic soils on the northeastern Kilimanjaro slope dominate around the southeast, which favors crop production while the southeast part of Ilkisongo is covered by basement rock soils making it largely suitable for pastoralism.

The Area lies in ecological zone VI, and is generally arid to semi-arid savanna environment; with low agricultural potential [35]. It's characterized by spatial and temporal variation in hydrology, and surface water is only found in few permanent streams and rivers (Figure 1). The streams, rivers and existing water resources are predominantly a result of the hydrological influence of Mt. Kilimanjaro, where water flows underground

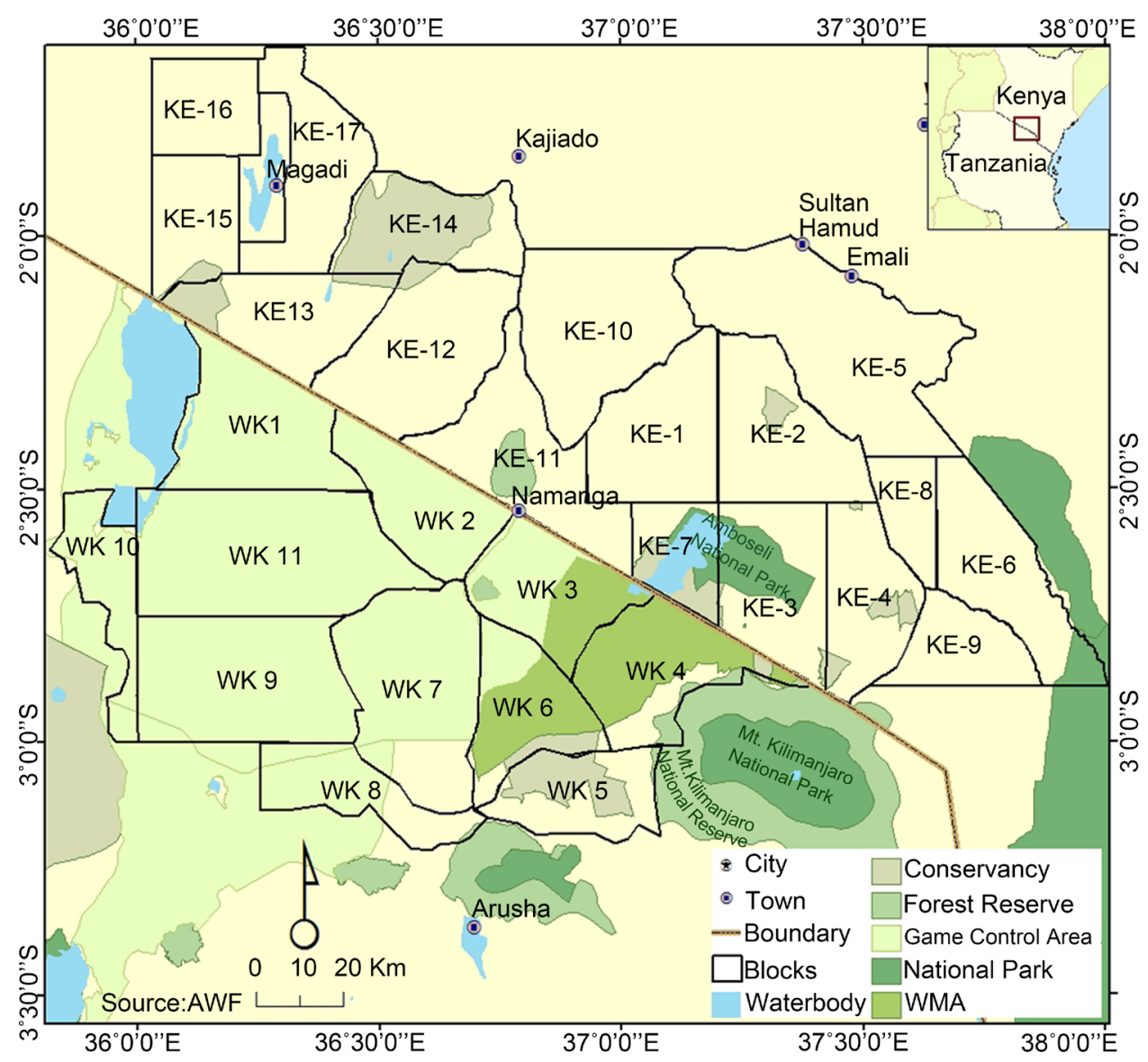

Figure 1. The Amboseli-West Kilimanjaro and Magadi-Natron landscapes along the KenyaTanzania border. 
and emerge elsewhere inform of streams, rivers or swamps [35]. These springs together with rainfall, feeds the rivers, streams and swamps in the area.

Rainfall in the borderland region is bimodal, unpredictable and unreliable [35]. The short rains occur between the end of October and mid-December, while the long rains fall between March and May [36], and the mean annual rainfall across the area ranges from 400 to $1000 \mathrm{~mm}$ [37]. The October-December rainfall accounts for $45 \%$, and the March-May for $30 \%$ of the total rainfall, which means it's the single most important factor influencing land use practices, which currently include agriculture, pastoralism and wildlife conservation [35]. Human population growth in the region especially within the group ranches and along the slopes of Mt. Kilimanjaro has been rapid, and population in the area more than doubled between 1979 and 1999 [37]. Over the past 15 years the number of registered members within the Kimana, Kuku, and Mbirikani group ranches has increased by 505\%, 1323\%, and 497\%, respectively [35]. This rapid population increase is due to the immigration of non-pastoral people seeking access to more productive land within the group ranches [35]. At the same time, the land within the group ranches has experienced extensive changes over the past 30 years in response to a variety of economic, cultural, political, institutional, and demographic processes [37]. Pastoralism, which was once the backbone of the Maasai livelihood, has declined tremendously, partly as a result of increased agricultural activities that have become widespread in the entire region [35].

The vegetation of the region is typical of a semi-arid environment. Dominant vegetation types are; open grasslands towards the north and northeast to the Chyulu Hills, Acacia dominated bushland southward to the forest belt of Mt. Kilimanjaro. In these main types, there are patches of swamps and swamp-edge grasslands and Acacia woodlands [35].

\subsection{Methods}

Even though aerial count was generally done for large mammals, this survey specifically targeted all Maasai ostrich in the survey. Total aerial counts of elephants and key large herbivorous wildlife species were conducted during the start of rain season in the 2010 ( $11^{\text {th }}$ to $16^{\text {th }}$ October at the end of dry season) and 2013 ( $6^{\text {th }}$ to $12^{\text {th }}$ October) based on the technique [38]. The count therefore employed the Global Positioning System (GPS) technique with Arc View software used for plotting species distribution maps. Counts were done within blocks demarcated based on well-defined laid out fly paths (Figure 2) on the ground using features such as; roads, rivers, hills etc. in an average area of 7852 $\mathrm{km}^{2}$. These features were meant to make it easier for pilots to navigate the blocks [39], thus the counting blocks design was demarcated so as to conform to the following rules; i) rivers were not used as boundaries of the blocks. Rivers are normally areas of concentration of animals hence not suitable as boundaries for counting blocks owing to the necessity to turn over this area and begin a new transect and the high possibility animals would move from one side of the river to the other, resulting in double counts, ii) blocks were made rectangular or square in shape, which eased navigation for the pilots 


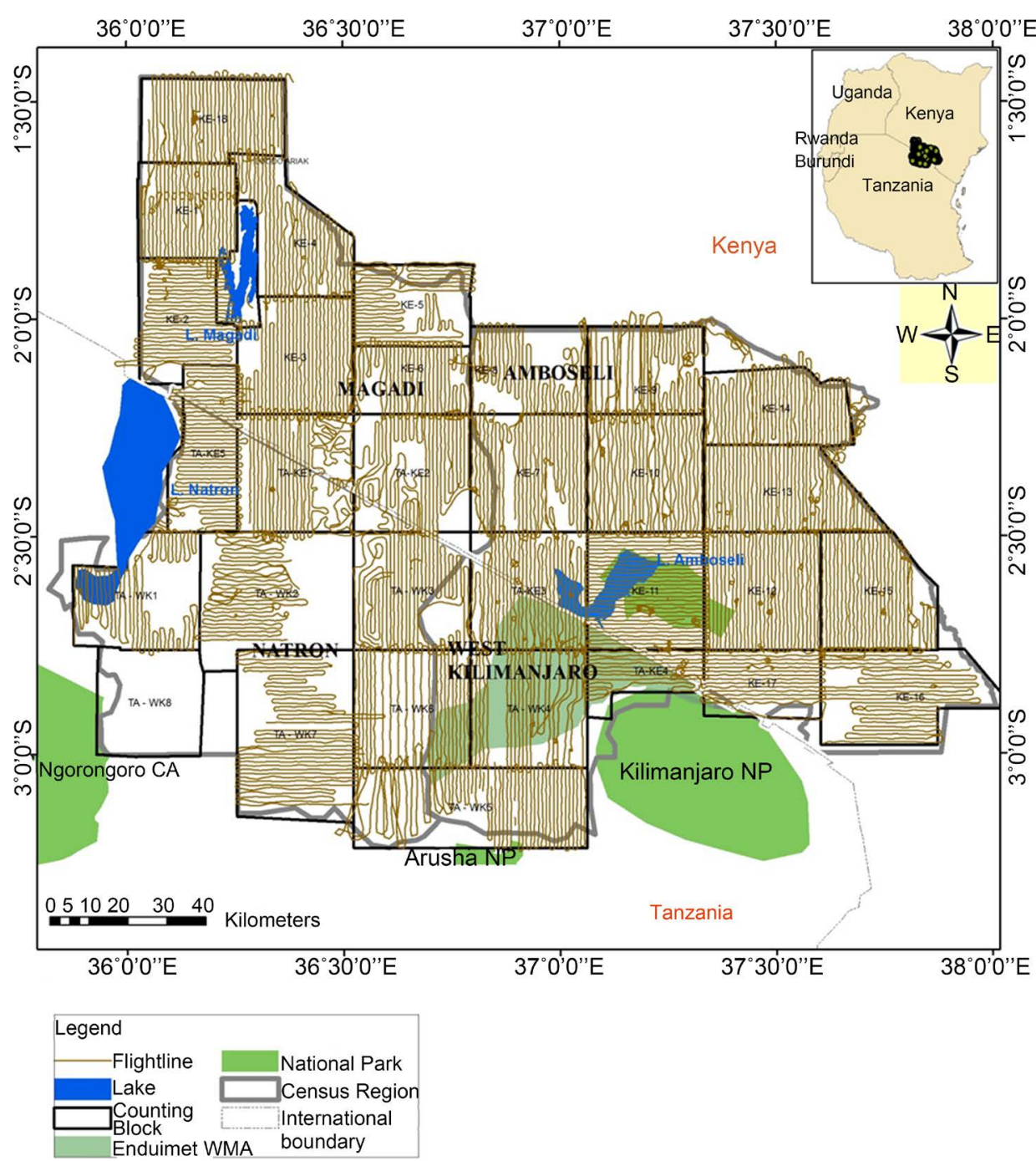

Figure 2. Layout of the census flight paths and flights paths in the study area.

and FSOs using GPS and allowed more time for observations, iii) blocks were made small enough to be counted within a maximum of six hours a day, and an area of 900 $\mathrm{km}^{2}$ was deemed a suitable average size of a block, and, iv) block boundaries did not cut across areas of high wildlife density as determined by kernel densities from previous surveys.

To improve the quality of data collected on wildlife populations, the crew was trained on use of various counting and estimation techniques, use of equipment (GPS, voice recorders and cameras), species identification and estimation, data handling and processing. Practical training sessions and test flights were included as rehearsal for the actual census. The test flights involved the different flight crews flying the same mock transects at different intervals while maintaining same orientation in order to assess inter observer variability in species detection, estimation and identification. Thereafter, each block was systematically searched using light air-crafts flying either North South or East West directions along transects of $1-2 \mathrm{~km}$ width depending on visibility and 
terrain (Figure 3). The aircraft crew consisted of a pilot, Front Seat Observer (FSO) and Rear Seat Observer (RSO). The aircraft crew systematically searched for and made observations and recording of elephants and key large wildlife species and their number along the flight transects [38]. For each observation a waypoint was marked using a hand held Global Positioning System (GPS) and the observation recorded on a data sheet. Tape recorders were also used to aid in data capture and data were transcribed into the datasheet after every survey session. Large herds of more than 10 individuals were photographed unless the view was obstructed by thick vegetation, in order to establish the correct count (Douglas-Hamilton, 1996). At the end of each count session, the GPS flight paths and waypoints were down loaded using DNR-Garmin/MapSource software, and the Front Seat Observers (FSO) did a summary table of each block [39]. Any double counts in neighboring blocks were also validated worked out and eliminated during these sessions. Voice records were processed digitally to remove background noises and improve the clarity. A team of data handlers transcribed the voice records onto datasheets and entered these into a digital database. The exercise started every morning at around 7.30 am and ended in the afternoon. End time was variable because it depended on the size of the blocks, and rest breaks were taken during refueling of the aircrafts and at lunch time. Flight path and way point data were processed using ArcGIS 9.3 program, while the observation data sheets were cleaned and entered into Microsoft Excel 2003/2007 for further analysis.

\subsection{Data Analysis}

Only data for the dry period of 2007, 2010 and 2013 were used. Tallies, percentages, means and standard errors for the data were calculated using standard statistical methods [40]. Population changes were done based on the density of the 2010 and assessing as a percentage, how values varied before that year (for 2007) and how values varied after that year (2013). Chi-square cross-tabulations were done to establish the association between species numbers and the counting areas (group ranch locations), and

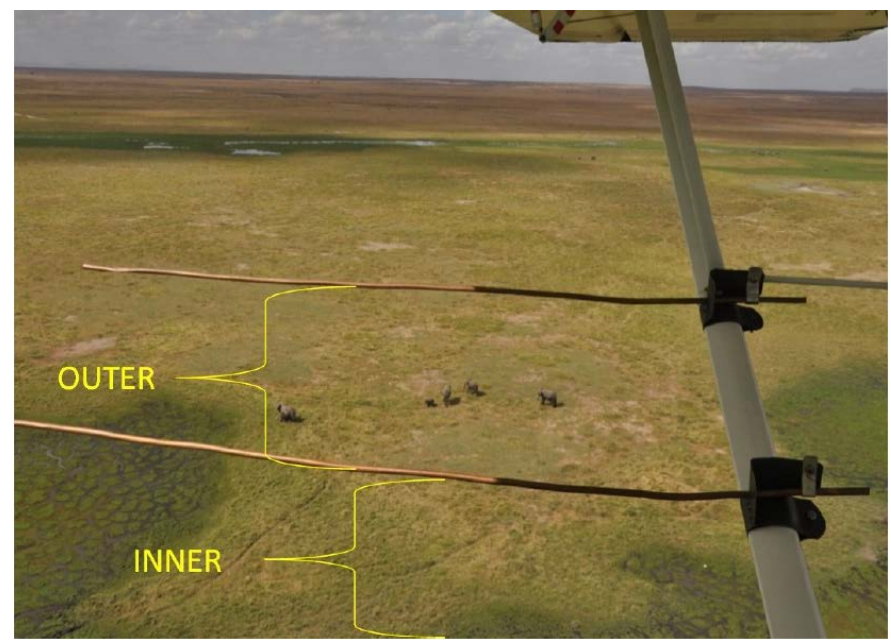

Figure 3. Position of steamers on the wings of an aircraft. 
between species numbers and years (effect of drought periods) using SPSS statistical software. Even though the dry season census area of the year 2007 was $5,542 \mathrm{~km}^{2}$ mainly in Amboseli Ecosystem, the census area increased to $24,000 \mathrm{~km}^{2}$ in 2010 and further to $25,623 \mathrm{~km}^{2}$ in 2013 to cover the entire Kenya/Tanzania borderland. The total numbers may therefore be affected by the size, but the density and proportions of each species of the large mammals seen were reliable measures for comparison due to weighting per unit area and as a proportion.

\section{Results}

The Maasai ostrich was well represented in all the landscapes and ecosystems (protected areas and dispersal areas) along the Kenya-Tanzania borderland from the end of Tsavo-Mukomazi ecosystem to that of Natron-Magadi areas during the 2010 and 2013 counts. Amboseli and its surrounding group ranches had the highest number of Maasai ostrich (Table 1) in the borderland (averaging $726.0 \pm 100.9$ ostriches), followed by Lake Natron area (330.8 \pm 69.8 ostriches), Magadi/Namanga (261.0 \pm 50.9 ostriches), and lastly West Kilimanjaro area (85.5 \pm 18.0 ostriches).

Table 1. Maasai ostrich numbers and density in the key population hotspots of the Kenya/Tanzania borderland.

\begin{tabular}{|c|c|c|c|c|c|c|}
\hline Location & Year & Season & $\begin{array}{c}\text { Census } \\
\text { area } \\
\left(\mathrm{km}^{2}\right)\end{array}$ & $\begin{array}{l}\text { Ostrich } \\
\text { numbers }\end{array}$ & $\begin{array}{c}\text { Ostrich } \\
\text { density (per } \\
\mathrm{km}^{2} \text { ) }\end{array}$ & $\begin{array}{l}\text { Proportion (\%) } \\
\text { ostrich numbers in } \\
\text { the borderland }\end{array}$ \\
\hline \multirow{5}{*}{$\begin{array}{c}\text { Amboseli and } \\
\text { surrounding group } \\
\text { ranches }\end{array}$} & \multirow{2}{*}{2010} & Wet & 8797.00 & 876 & 0.10 & 59.96 \\
\hline & & Dry & 8797.00 & 630 & 0.07 & 55.17 \\
\hline & \multirow{2}{*}{2013} & Wet & 9214.44 & 910 & 0.10 & 47.40 \\
\hline & & Dry & 9214.44 & 488 & 0.05 & 44.77 \\
\hline & \multicolumn{2}{|c|}{$\begin{array}{c}\text { Overall } \\
(\text { Mean } \pm \text { SE })\end{array}$} & - & $726.0 \pm 100.9$ & $0.08 \pm 0.01$ & $51.82 \pm 3.50$ \\
\hline \multirow{5}{*}{$\begin{array}{c}\text { Magadi/Namanga } \\
\text { Areas }\end{array}$} & \multirow{2}{*}{2010} & Wet & 5513.00 & 335 & 0.06 & 22.93 \\
\hline & & Dry & 5513.00 & 130 & 0.02 & 11.38 \\
\hline & \multirow{2}{*}{2013} & Wet & 6348.32 & 348 & 0.05 & 18.13 \\
\hline & & Dry & 63.48 .32 & 231 & 0.04 & 21.19 \\
\hline & \multicolumn{2}{|c|}{$\begin{array}{c}\text { Overall } \\
(\text { Mean } \pm \text { SE })\end{array}$} & - & $261.0 \pm 50.9$ & $0.04 \pm 0.01$ & $18.41 \pm 2.54$ \\
\hline \multirow{5}{*}{$\begin{array}{c}\text { West Kilimanjaro } \\
\text { Area }\end{array}$} & \multirow{2}{*}{2010} & Wet & 3014.00 & 61 & 0.02 & 4.18 \\
\hline & & Dry & 3014.00 & 68 & 0.02 & 5.95 \\
\hline & \multirow{2}{*}{2013} & Wet & 3013.18 & 139 & 0.05 & 7.24 \\
\hline & & Dry & 3013.18 & 74 & 0.02 & 6.79 \\
\hline & \multicolumn{2}{|c|}{$\begin{array}{c}\text { Overall } \\
(\text { Mean } \pm \text { SE })\end{array}$} & - & $85.5 \pm 18.0$ & $0.03 \pm 0.01$ & $6.04 \pm 0.68$ \\
\hline \multirow{5}{*}{ Lake Natron Area } & \multirow{2}{*}{2010} & Wet & 7047.00 & 189 & 0.03 & 12.94 \\
\hline & & Dry & 7047.00 & 314 & 0.04 & 27.50 \\
\hline & \multirow{2}{*}{2013} & Wet & 7047.26 & 523 & 0.07 & 27.24 \\
\hline & & Dry & 7047.26 & 297 & 0.04 & 27.25 \\
\hline & \multicolumn{2}{|c|}{$\begin{array}{c}\text { Overall } \\
(\text { Mean } \pm \text { SE })\end{array}$} & - & $330.8 \pm 69.8$ & $0.05 \pm 0.01$ & $23.73 \pm 3.60$ \\
\hline
\end{tabular}


In terms of the proportion of ostrich numbers in each location of the borderland counted (Figure 4), Amboseli and surrounding group ranches led (51.82 $\pm 3.50 \%)$ followed by a distant Lake Natron area $(23.73 \pm 3.60 \%)$, Magadi/Namanga area (18.41 \pm $2.54 \%)$, and lastly West Kilimanjaro $(6.04 \pm 0.68 \%)$. Further, in terms of ostrich density (Figure 5), Amboseli and its surrounding group ranches had also the highest ostrich density (Table 1 ) in the borderland (averaging $0.08 \pm 0.01$ ostriches per $\mathrm{Km}^{2}$ ), followed

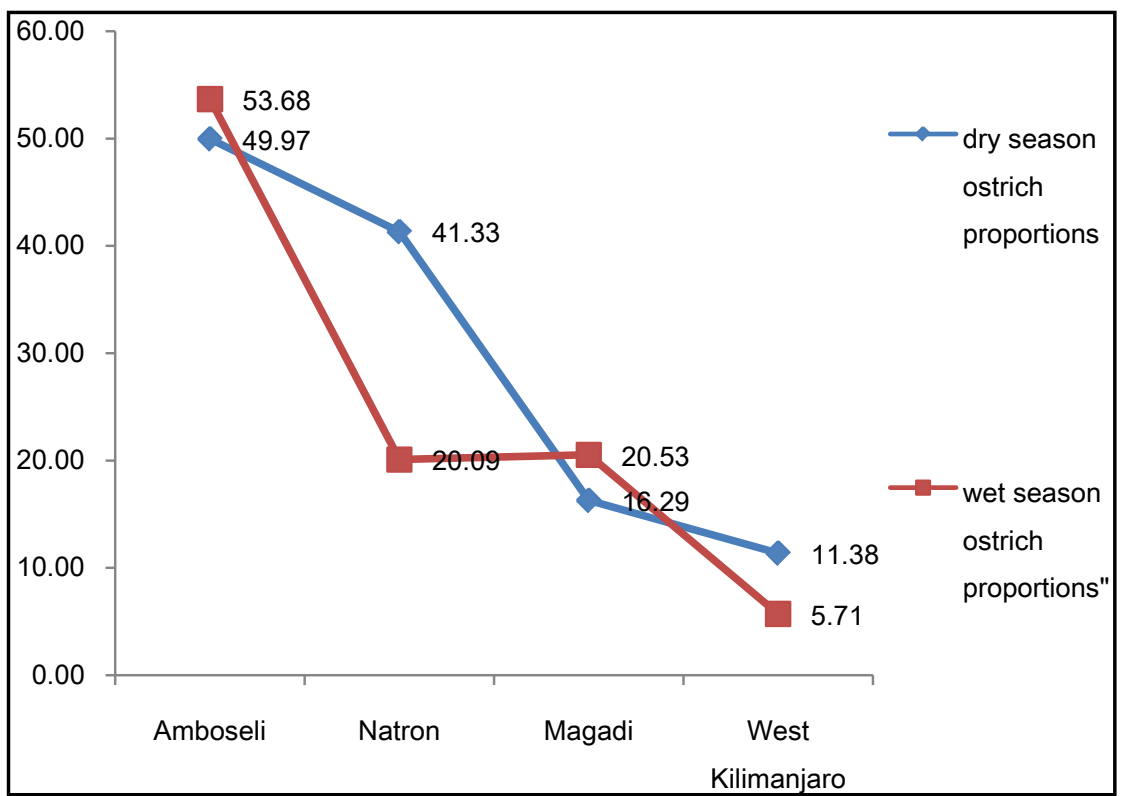

Figure 4. Proportions (\%) Maasai ostrich in the wet and dry season in Kenya-Tanzania borderland.

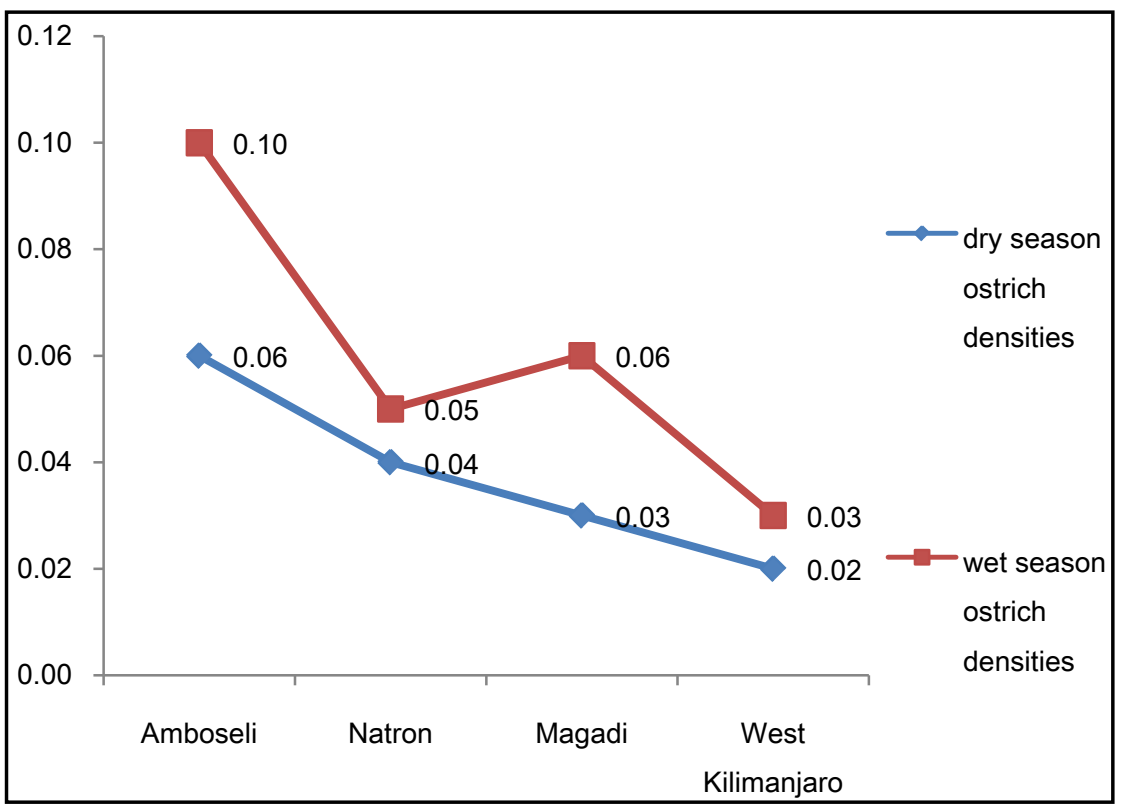

Figure 5. Maasai ostrich densities $\left(\#\right.$ per $\mathrm{km}^{2}$ ) in the wet and dry season in the Kenya-Tanzania borderland. 
by Lake Natron area $\left(0.05 \pm 0.01\right.$ ostriches per $\left.\mathrm{km}^{2}\right)$, Magadi/Namanga area $(0.04 \pm 0.01$ ostriches per $\left.\mathrm{km}^{2}\right)$, and West Kilimanjaro area $\left(0.03 \pm 0.01\right.$ ostriches per $\left.\mathrm{Km}^{2}\right)$.

Generally the Maasai ostrich populations seemed to be increasing in most locations from 2010 (after experiencing the drought of 2009). Further, the wet season numbers and densities seemed to be higher compared to the dry season within and between the years except for 2010 dry season when numbers in Lake Natron area and West Kilimanjaro were higher in dry season than in wet season (Table 1). Considering changes in the density in each of the locations of the borderland, Amboseli had the most negative change (decline in ostrich over time) in density with $-13.44 \pm 12.61$, compared to other locations in the borderland (Table 2).

The highest positive growth (increase in ostrich numbers over time) in ostrich density in the borderland was in Lake Natron area $(+85.65 \pm 91.06)$ followed by West Kilimanjaro area $(+68.39 \pm 59.54)$, and lastly for positive growth (increase in ostrich numbers overt time) was Magadi area with $+22.26 \pm 32.05$. The high variation in Magadi/Namanga area ostrich density was possibly because the area witnessed an ostrich density decline (negative growth) between the wet season of 2010 and 2013 (Table 2). This wet season decline in ostrich density was therefore seen in Amboseli area and Magadi/Namanga.

Considering changes in the number of ostrich proportion (\%) of all borderland ostrich in each of the locations of the borderland between 2010 and 2013, similar trends as changes in density were observed (Table 2). Lake Natron area the highest positive growth (increase) in the proportion of ostriches in the borderland (+85.65 \pm 91.07$)$

Table 2. Maasai ostrich numbers and density changes in wet and dry seasons between 2010 and 2013.

\begin{tabular}{|c|c|c|c|c|c|}
\hline Location & Season & $\begin{array}{c}\text { Ostrich } \\
\text { density } \\
(\text { per km²) } \\
(\text { mean } \pm \\
\text { SE) }\end{array}$ & $\begin{array}{c}\text { Ostrich \% } \\
\text { numbers in } \\
\text { location (mean } \\
\pm \mathrm{SE} \text { ) }\end{array}$ & $\begin{array}{l}\text { Change (\%) in } \\
\text { ostrich density } \\
\text { over } 3 \text { years }\end{array}$ & $\begin{array}{c}\text { Change }(\%) \text { in } \\
\text { ostrich proportion } \\
\text { over the } 3 \text { years }\end{array}$ \\
\hline \multirow{3}{*}{$\begin{array}{c}\text { Amboseli and } \\
\text { surrounding group } \\
\text { ranches }\end{array}$} & Wet & $0.10 \pm 0.00$ & $53.68 \pm 6.28$ & -0.82 & +3.88 \\
\hline & Dry & $0.06 \pm 0.01$ & $49.97 \pm 5.20$ & -26.05 & -22.54 \\
\hline & Overall & $0.08 \pm 0.01$ & $51.82 \pm 3.50$ & $-13.44 \pm 12.61$ & $-9.33 \pm 13.21$ \\
\hline \multirow{3}{*}{$\begin{array}{c}\text { Magadi and } \\
\text { Namanga Areas }\end{array}$} & Wet & $0.06 \pm 0.00$ & $20.53 \pm 2.40$ & -9.79 & +3.88 \\
\hline & Dry & $0.03 \pm 0.01$ & $16.29 \pm 4.90$ & +54.31 & +77.69 \\
\hline & Overall & $0.04 \pm 0.01$ & $18.41 \pm 2.54$ & $+22.26 \pm 32.05$ & $+40.79 \pm 36.91$ \\
\hline \multirow{3}{*}{$\begin{array}{c}\text { West Kilimanjaro } \\
\text { Area }\end{array}$} & Wet & $0.03 \pm 0.01$ & $5.71 \pm 1.53$ & +127.93 & +127.87 \\
\hline & Dry & $0.02 \pm 0.00$ & $6.37 \pm 0.42$ & +8.85 & +8.82 \\
\hline & Overall & $0.03 \pm 0.01$ & $6.04 \pm 0.68$ & $+68.39 \pm 59.54$ & $+68.35 \pm 59.52$ \\
\hline \multirow{3}{*}{ Lake Natron Area } & Wet & $0.05 \pm 0.02$ & $20.09 \pm 7.15$ & +176.71 & +176.72 \\
\hline & Dry & $0.04 \pm 0.00$ & $27.37 \pm 0.12$ & -5.42 & -5.41 \\
\hline & Overall & $0.05 \pm 0.01$ & $23.73 \pm 3.60$ & $+85.65 \pm 91.06$ & $+85.65 \pm 91.07$ \\
\hline
\end{tabular}


followed by West Kilimanjaro area $(+68.35 \pm 59.52)$ in ostrich proportion of population in the borderland areas. The third location in proportion of ostrich in the borderland was Magadi/Namanga area with $+40.79 \pm 36.91$. Lake Natron, Magadi/Namanga and West Kilimanjaro all had positive growth (increase) in ostrich numbers over time in both wet and dry season (Table 2). But Amboseli area had a negative (decline in ostrich numbers) in the dry season, but positive (increase) in the wet season, with an average overall negative (decline) change of ostrich number proportion of $-9.33 \pm 13.21$ in the borderland (Table 2).

In terms of seasonal comparison, all the locations (except one dry season of 2010 in West Kilimanjaro) in the borderland had different ostrich numbers between wet and dry season of every year; and between dry season numbers and wet season numbers. Ostrich numbers generally increased with time except for Amboseli in the wet seasons of subsequent years, and West Kilimanjaro and Lake Natron area in the dry season of subsequent years in which ostrich numbers were similar (Table 3). In Lake Natron for

Table 3. The differences in Maasai ostrich numbers between seasons and within season in various locations within the Kenya-Tanzania borderland.

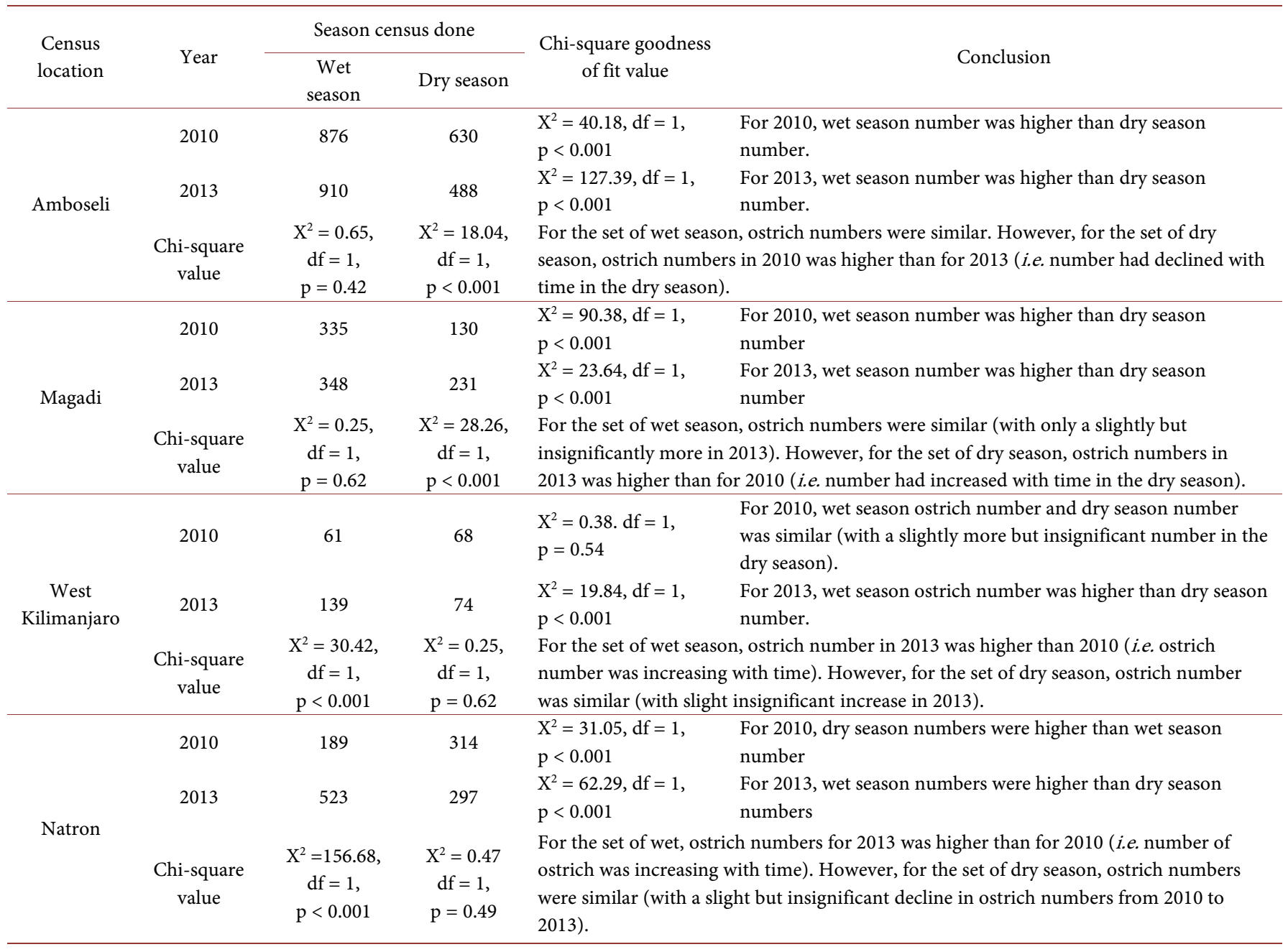


example, ostrich numbers were higher $(\mathrm{p}<0.01)$ in the dry season than wet season for 2010. Similarly for West Kilimanjaro, the dry season numbers were higher, although not significantly so $(p>0.05)$ than the west season (Table 3$)$. But generally, there were more ostrich in the wet season than in dry season, and increased over the years from 2010 to 2013 (Table 3).

In Amboseli area for 2010, wet season ostrich number was higher $(\mathrm{p}<0.01)$ than dry season number. Similarly, in 2013, wet season ostrich number was also higher ( $\mathrm{p}<$ 0.01 ), than dry season ostrich number. However, for subsequent wet and dry season, ostrich numbers were significantly higher $(\mathrm{p}<0.01)$ for 2013 than 2010 in the dry season, but the numbers were similar in the wet season $(\mathrm{p}=0.42)$ for Amboseli area (Table 3). Similar trend was observed for Magadi/Namanga area, with wet season ostrich number being higher $(\mathrm{p}<0.01)$ than dry season number in 2010, and also wet season ostrich number being higher $(p<0.01)$ than dry season number in 2013. Further, for subsequent wet and dry season, ostrich numbers were significantly higher $(\mathrm{p}<$ 0.01) for 2013 than 2010 in the dry season, but the numbers were similar in the wet season ( $\mathrm{p}=0.62)$ for Magadi/Namanga area (Table 3).

In West Kilimanjaro for 2010, wet season numbers was similar $(\mathrm{p}=0.54)$ than dry season ostrich number. However, for 2013, dry season numbers were higher $(\mathrm{p}<0.01)$ than wet season number. Further, for each subsequent set of wet and dry season, the ostrich numbers were not consistent. They were higher $(p<0.01)$ in the wet season of 2013 than 2010, but similar $(\mathrm{p}=0.62)$ in the dry season of 2010 and 2013 in West Kilimanjaro area (Table 3). Similar trend was observed for Lake Natron area, with wet season ostrich numbers being higher $(\mathrm{p}<0.01)$ than dry season number in 2010. But in 2013, dry season numbers were higher $(p<0.01)$ than wet season numbers. Further, for each subsequent set of wet and dry season, the ostrich numbers were not consistent as well. They were higher $(\mathrm{p}<0.01)$ in the wet season of 2013 than 2010 , but similar $(\mathrm{p}<$ 0.01 ) in the dry season of 2010 and 2013 (Table 3).

In terms relationships in ostrich numbers in different locations (closer or further away from protected areas) with season varied among the locations in the borderland (Table 4). Generally ostrich number in locations was dependent (chi-square cross tabulations, $\mathrm{p}<0.001$ ) on season, with ostrich numbers increasing everywhere in the wet season, but more so near protected areas than further way in the wet season. In the wet season specifically, ostrich number in a location was dependent on the year, with ostrich numbers increasing over time near protected areas, and more so further from protected areas $(\mathrm{p}<0.001)$. In the dry season, ostrich number in locations was also dependent $(\mathrm{p}<0.001)$ on year, but with ostrich numbers increasing near protected areas, but less further away from protected areas (Table 4).

Even though the Maasai ostrich were widely distributed in the landscape, there higher presence occurred in the Amboseli and the surrounding group ranches and across Namanga to Magadi on the Kenyan side. On the Tanzanian side, the Maasai ostrich present seem to be relatively more on the Lake Natron area and relatively fewer in the West Kilimanjaro area. Relatively more ostrich was found on the Kenyan side of the 
Table 4. The relationship between Maasai ostrich numbers and census location proximity to existing protected areas (Amboseli and West Kilimanjaro) and away (Magadi and Lake Natron area) within the borderland.

\begin{tabular}{|c|c|c|c|c|c|}
\hline \multirow{2}{*}{$\begin{array}{l}\text { Season } \\
\text { of the } \\
\text { year }\end{array}$} & \multirow[b]{2}{*}{ Year } & \multicolumn{2}{|c|}{ Location of census area } & \multirow{2}{*}{$\begin{array}{l}\text { Chi-square } \\
\text { cross } \\
\text { tabulation } \\
\text { value }\end{array}$} & \multirow[b]{2}{*}{ Conclusion } \\
\hline & & $\begin{array}{c}\text { In or around } \\
\text { protected } \\
\text { areas }\end{array}$ & $\begin{array}{c}\text { Away from } \\
\text { protected } \\
\text { areas }\end{array}$ & & \\
\hline $\begin{array}{c}\text { Wet } \\
\text { season }\end{array}$ & $\begin{array}{l}2010 \text { (after } \\
\text { drought) } \\
2013 \text { (post } \\
\text { drought) }\end{array}$ & 1049 & 524 & $\begin{array}{c}\mathrm{X}^{2}=30.89 \\
\mathrm{df}=1 \\
\mathrm{p}<0.001\end{array}$ & $\begin{array}{l}\text { In the wet season, ostrich } \\
\text { number in locations was } \\
\text { dependent on year, with the } \\
\text { number increasing over time } \\
\text { near protected areas, and more } \\
\text { so further from protected areas }\end{array}$ \\
\hline $\begin{array}{c}\text { Dry } \\
\text { season }\end{array}$ & $\begin{array}{c}2010 \text { (after } \\
\text { drought) }\end{array}$ & 968 & 528 & $\begin{array}{c}\mathrm{X}^{2}=74.79 \\
\mathrm{df}=1 \\
\mathrm{p}<0.001\end{array}$ & $\begin{array}{l}\text { In the dry season, ostrich } \\
\text { number in locations was } \\
\text { dependent on year, with } \\
\text { ostrich numbers increasing } \\
\text { near protected areas, but less } \\
\text { further away from protected } \\
\text { areas }\end{array}$ \\
\hline $\begin{array}{l}\text { Overall } \\
\text { wet } \\
\text { season } \\
\text { Overall } \\
\text { dry } \\
\text { season }\end{array}$ & & 1286 & 1395 & $\begin{array}{c}\mathrm{X}^{2}=35.12 \\
\mathrm{df}=1 \\
\mathrm{p}<0.001\end{array}$ & $\begin{array}{l}\text { Generally ostrich number in } \\
\text { locations was depended on } \\
\text { season, with ostrich numbers } \\
\text { increasing everywhere, but } \\
\text { more so near protected areas } \\
\text { than further way in the wet } \\
\text { season. }\end{array}$ \\
\hline
\end{tabular}

borderland land than in Tanzania, and distributions seems more spread for the wet season (Figure 6 and Figure 7) than in the dry (Figure 8 and Figure 9).

\section{Discussion}

The Maasai ostrich is still widely distributed in the Kenyan/Tanzanian borderland than most herbivores, but looking at their distribution they are increasingly being confined to certain areas and not present in some. The distribution showed that over half of the ostrich population in the borderland was in Amboseli area, and most of their presence being on the Kenyan side of the border. Therefore, like with other large mammals and wildlife species, Amboseli area still the most important area in the borderland for ostrich conservation, and therefore conservation of the Amboseli Ecosystem must remain a priority especially for Kenya Wildlife Service. But there was also good ostrich presence in the Magadi/Namanga area and Lake Natron areas. It is emerging that habitat destruction and ostrich poaching could be the main threats to this bird species, although it can do well in many areas of even some pastoral human presence if poaching is contained. Ostrich numbers have also become a concern in the borderland ecosystems because they have become popular and easy targets for bush meat trade.

Despite Amboseli supporting more than half of the Maasai ostrich in the borderland, the fastest growth in density and numbers of ostrich was in Magadi and Lake Natron. So while we must continue to strengthen ostrich protection near and around the 


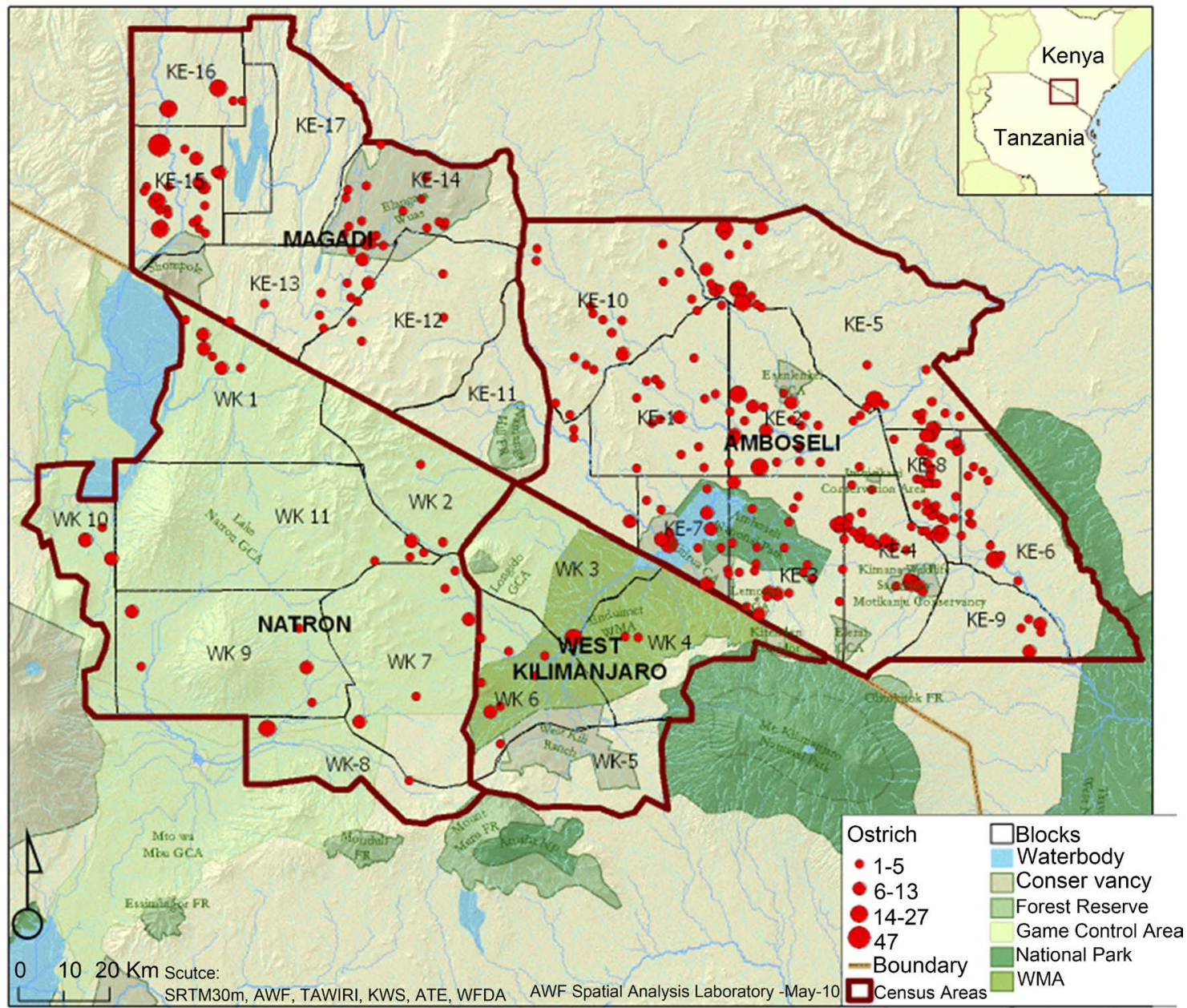

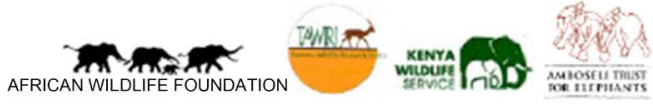

Distribution of Ostrich

Figure 6. Maasai ostrich distribution in the Kenya-Tanzania borderland during the 2010 wet season census.

protected areas in Amboseli and West Kilimanjaro, we must focus on unprotected areas in the borderland as well. This area therefore represents a much more promising area for ostrich population growth and source for other sink areas in the borderland area. The fact that the growth in these two locations (Magadi and Lake Natron block) was faster than in Amboseli and West Kilimanjaro suggests that there is still great potential for ostrich and the carrying capacity for this game bird may not have been reached yet in these two areas. It is therefore important to secure not only natural ostrich habitats of continuous undegraded (and not over-grazed) grassland and bushlands, but also security of ostrich from poachers. Since ostrich are not the main prey items for key carnivores like lions, spotted hyena and cheetah (though they can opportunistically be take especially by the leopards) poaching by humans (for bush meat), human encroachment and habitat destruction (habitat clearing for represents the common threats to ostrich in the borderland.

It is likely that these ostrich populations are connected as a Meta-population which is 


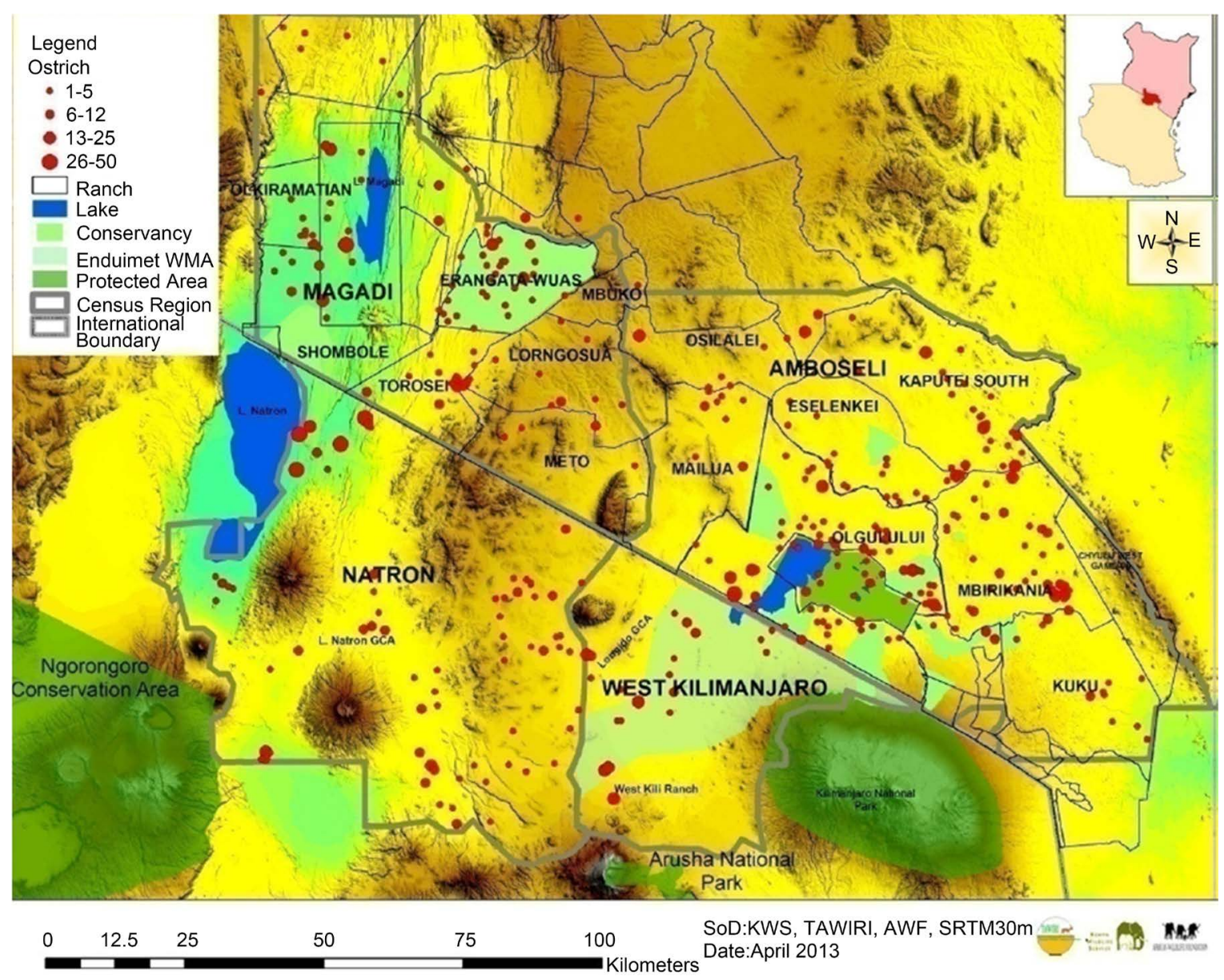

Figure 7. Maasai ostrich distribution in the Kenya-Tanzania borderland during the 2013 wet season census.

stabilized by each other in the borderland area. It is therefore very important that key corridors and connectivity pathways are maintained across the border between Magadi and Lake Natron on one hand, between Lake Natron and West Kilimanjaro through the expansive Longido rangelands, and between West Kilimanjaro and Amboseli. Natural vegetation with good tree and shrub cover and minimal degradation by human impacts and overgrazing will allow for this critical connectivity between these ecosystems so as to continue to maintain the larger borderland ostrich meta-population. There seems to be threats to this connectivity by observing the distribution. The main Nairobi-Namanga-Arusha highway is inspiring growth and expansion of old towns (Kajiado, Isibil, Namanga, Longido, Oldonyo Sambu, etc) which are likely to cut off connectivity in the borderland for continuous ostrich habitats that will allow social and genetic interactions of different populations in the borderland. New road expansion and settlement, overgrazing, destruction and over-use of tree and shrub resources, and general human population increase are likely to cut off connectivity in ostrich populations in the borderland. Increasing charcoal kilns in the borderland rangeland lends support to this concern.

Maasai ostrich numbers were generally increasing in all the areas of the borderland, 


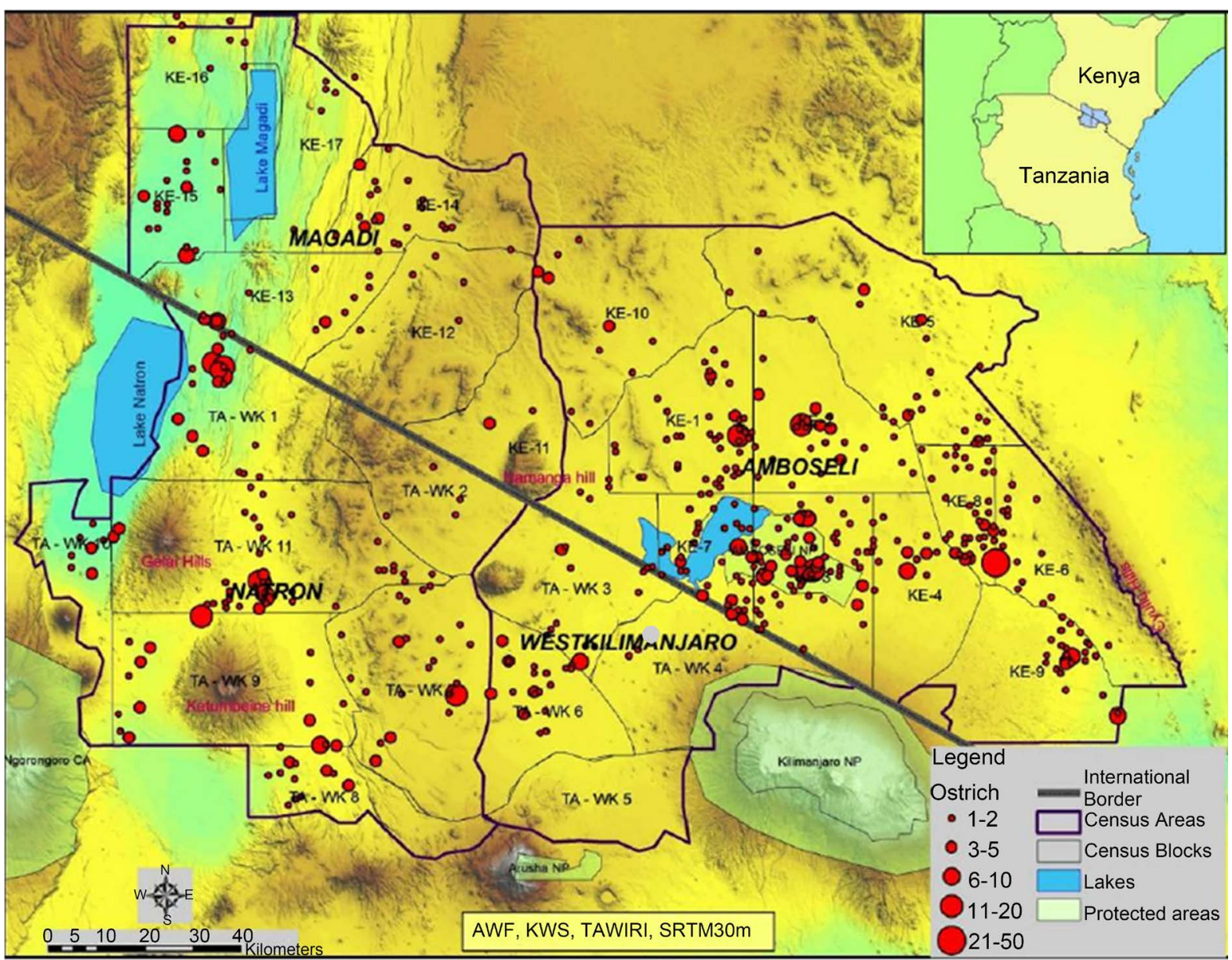

Figure 8. Maasai ostrich distribution in the Kenya-Tanzania borderland during the 2010 dry season census.

especially in the wet season after the devastating effects of 2007-2009 droughts in the borderland ecosystems. This is expected because wet season is associated with lush growth in vegetation and plenty of available surface water. Much forage and water will improve not only resources for ostrich growth, viability and reproduction fitness, but will also provide thermal cover and reduced competition with cattle and other large wild herbivores for plant resources and water. Like other borderland wild herbivores, they also disperse widely during the wet season, but range in specific woodlands and riverine areas in dry season. Even though Maasai ostrich can take long (up to three days) before drinking water, they still need free water for drinking, and this explains why they range closely to Amboseli and Lake Natron especially during the dry season. Nevertheless, ostrich can also get (preformed) water from eating lush vegetation because green fresh plant leave tissues contained water which will often meet metabolic requirements of ostrich, especially in dry season and areas of water scarcity. It is therefore critical to protect critical riverine natural habitats from agricultural expansion in the borderland so that they are available to ostrich and other wild animals especially in the dry season.

We generally expected ostrich populations to be increasing in Lake Natron and West 


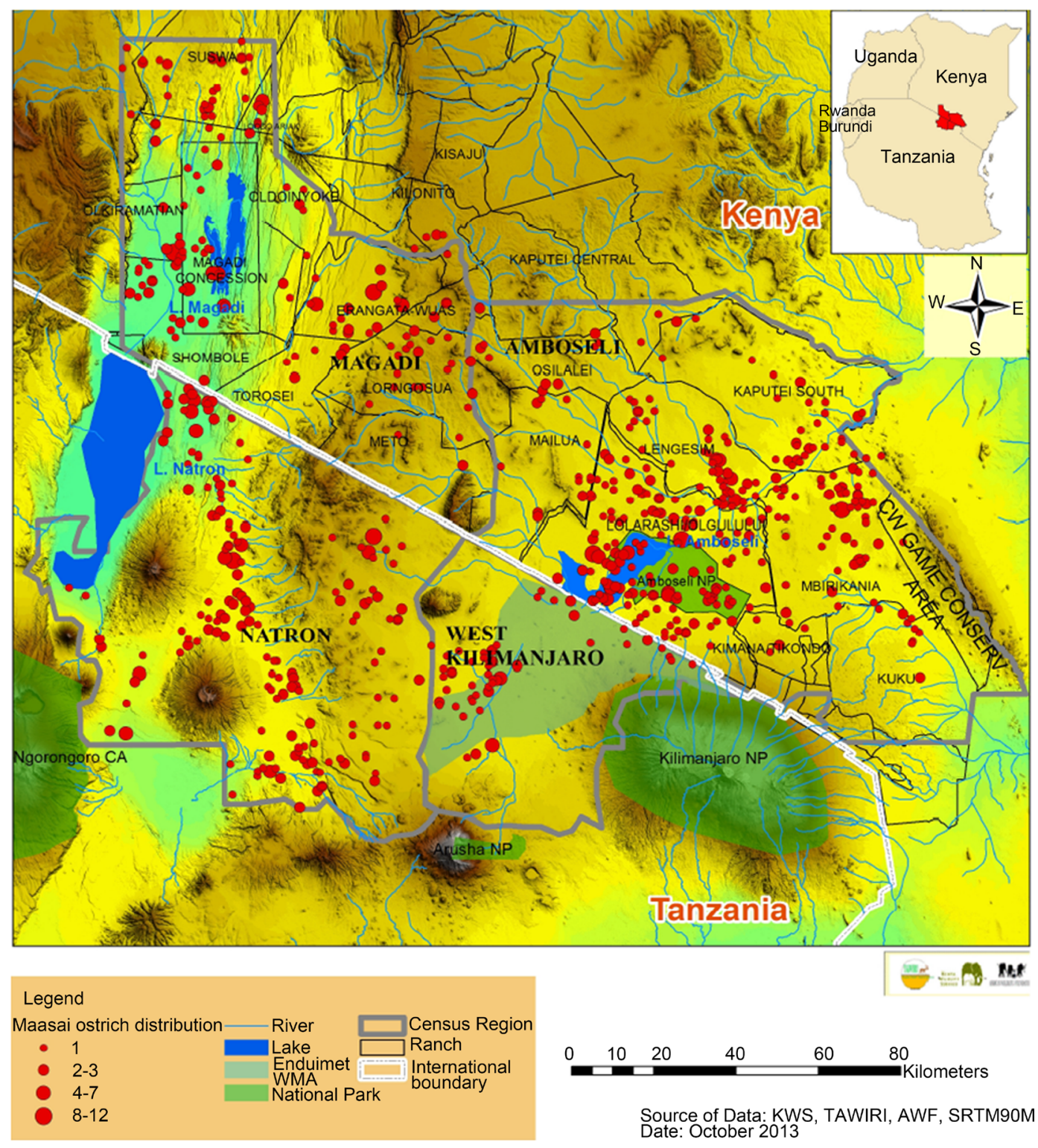

Figure 9. The Maasai ostrich distribution in the Kenya/Tanzania borderland during the 2013 dry season census.

Kilimanjaro locations from 2010 through 2013 as a recovery from droughts of 2007 and 2009 , and in the wet season when forage is more plentiful. However, this was not the case as the dry season ostrich numbers were higher than the wet season in 2010. Two reasons may explain this, first that in some areas, ostrich numbers will concentrate in places where there is more water availability, partly to access free flowing water, but secondly and more importantly because such areas may be associated with lush grass and forbs, and a variety of insects that will provide critical forage in the dry season. Since this may be accompanied by reduced landscape ranging and movements as ostrich settle in places where forage availability and distribution will likely support them more in the dry season, these may lead to enhanced concentration of ostrich in such 
places and hence have a more elevated ostrich numbers in dry season than the wet season when they disperse more and venture in other areas due to a wide availability of forage. This may also explain why ostrich density and numbers were relatively more in the dry season of 2010 (which was recovering from a longer drought) than the dry season of 2013.

Results indicated that in the wet season, ostrich number increased everywhere in the borderland, especially in the wet season. But in the dry season, ostrich numbers increased with time both near protected areas, but more so further away from the protected areas. This is an interesting finding because other than just highlighting the importance of protected areas for ostrich especially in the wet season, they highlights the critical role dispersal areas and other areas in the landscape not under protected area status for ostrich especially in the dry season. The increase in protected areas and away from protected areas in different seasons of the year underscores the need for a holistic and long-term strategy in ostrich conservation in increasing, and at a minimum maintaining its populations over time [41]. This calls for the increased involvement and encouragement of the landowners and communities on whose land Maasai ostrich roams outside of protected areas to support the initiative, develop conservation areas of their own and if possible be helped (in terms of capacity and technical support) to benefit from ecotourism ventures associated with ostrich and other large mammals on their land. This strategy will provide for more conservation space outside protected areas, but also encourage connectivity among key populations. The other critical consideration if the forming of partnerships and collaborative management between the communities and national government of Kenya and Tanzania to promote and enhance conservation of biodiversity across the borderland [42].

Even though the ostrich is a larger bird and can be seen from the air, there is a possibility that they can be missed during aerial counts because of their size, especially very young or female that is grey colored. This is especially possible in think vegetation or tall grass where ostrich may seek thermal shelter. It is therefore possible that the counts may have been an underestimate of the ostrich population.

\section{Conclusion}

The Maasai ostrich is still widely distributed in the Kenyan/Tanzanian borderland than most herbivores, but looking at their distribution they are increasingly being confined to certain areas and not present in some. Despite Amboseli supporting more than half of the Maasai ostrich in the borderland, the fastest growth in density and numbers of ostrich was in Magadi and Lake Natron and outside the protected areas. Therefore Amboseli seems to be a population source for ostrich that migrates in other areas where population growth is rapid in the Kenya-Tanzania borderland. The number of Maasai ostrich was generally increasing in all the areas of the borderland, especially in the wet season after the devastating effects of 2007-2009 droughts in the borderland ecosystems. Particularly, the number of ostrich increased everywhere in the borderland, especially in the wet season. But in the dry season, the number of ostrich increased with 
time both near protected areas, but more so further away from the protected areas. This is an interesting finding because other than just highlighting the importance of protected areas for ostrich especially in the wet season, they highlights the critical role dispersal areas and other areas play in the landscape not under protected area status for ostrich especially in the dry season.

\section{References}

[1] Sibley, C.G. and Monroe, B.L.J. (1990) Distribution and Taxonomy of Birds of the World. Yale University Press, New Haven.

[2] Brown, J.H., Urban, E.K. and Newman, K. (1992) The Birds of Africa, Vol. 1. Academic Press, London.

[3] Stevenson, T. and Fanshawe, J. (2002) Field Guide to the Birds of East Africa. T \& D Poyser.

[4] Zim, H.S. (2000) Ostriches. William Morrow, New York.

[5] Zimmerman, D.A., Donald, A.T. and Pearson, D.J. (1999) Birds of Kenya and Northern Tanzania. Princeton University Press, Princeton.

[6] Milton, S.J., Dean, W.R.J. and Siegfried, W.R. (1994) Food Selection by Ostrich in Southern Africa. Journal of Wildlife Management, 58, 234-248. http://dx.doi.org/10.2307/3809386

[7] Sauer, E.G.F. and Sauer, E.M. (1966) The Behavior and Ecology of the South African Ostrich. The Living Bird, 5, 45-75.

[8] Cloudsley-Thompson, J.L. and Mohamed, E.R.M. (1967) Water Economy of the Ostrich. Nature, 216, 1040. http://dx.doi.org/10.1038/2161040a0

[9] Withers, P.C. (1983) Energy, Water, and Solute Balance of the Ostrich Struthio camelus. Physiological and Biochemical Zoology, 56, 568-579. http://dx.doi.org/10.1086/physzool.56.4.30155880

[10] Louw, G.N., BeLouie, P.C. and Coetzee, H.J. (1969) Renal Function, Respiration, Heart Rate and Thermoregulation in the Ostrich (Struthio camelus). Scientific Papers of the Namib Desert Research Station, 42-54.

[11] Leuthold, W. (1977) Notes on the Breeding Biology of the Ostrich (Struthio camelus) in Tsavo East National Park, Kenya. IBIS, 119, 541-544. http://dx.doi.org/10.1111/j.1474-919X.1977.tb02067.x

[12] Bertram, B.C.R. (1992) The Ostrich Communal Nesting System. Princeton University Press, Princeton. http://dx.doi.org/10.1515/9781400863143

[13] BirdLife International (2004) Struthio camelus. IUCN Red List of Threatened Species. www.iucnredlist.org

[14] Campbell, K. and Hofer, H. (1995) People and Wildlife: Spatial Dynamics and Zones of Interaction. In: Sinclair, A.R.E. and Arcese, P., Eds., Serengeti II: Dynamics, Management, and Conservation of an Ecosystem, The University of Chicago Press, Chicago and London, 534-570.

[15] Hofer, H., Campbell, K.L.I., East, M.L. and Huish, S.A. (1996) The Impact of Game Meat Hunting on Target and Non-Target Species in the Serengeti. In: Taylor, J. and Dunstone, N., Eds., The Exploitation of Mammal Populations, Chapman and Hall, London, 117-146. http://dx.doi.org/10.1007/978-94-009-1525-1_9

[16] Ostrowski, S., Massalatchi, M.S. and Mamane, M. (2001) Evidence of a Dramatic Decline of the Red-Necked Ostrich Struthio camelus camelus in the Aïr and Ténéré National Nature Reserve, Niger. Oryx, 35, 349-352. http://dx.doi.org/10.1046/j.1365-3008.2001.00205.x 
[17] Diamond, A.W. (1986) A Global View of Cultural and Economic Uses of Birds. In: Diamond, A.W. and Filion, F.L., Eds., The Value of Birds, Technical Publication 6, International Council for Bird Preservation Cambridge, UK, 99-109.

[18] Thiollay, J.M. (2006) Large Bird Declines with Increasing Human Pressure in Savanna Woodlands (Burkina Faso). Biodiversity \& Conservation, 15, 2085-2108. http://dx.doi.org/10.1007/s10531-004-6684-3

[19] Thiollay, J.M. (2006) Severe Decline of Large Birds in the Northern Sahel of West Africa: A Long-Term Assessment. Bird Conservation International, 16, 353-365. http://dx.doi.org/10.1017/S0959270906000487

[20] Collar, N.J., Long, A.J., Robles, G.P. and Rojo, J. (2007) Birds and People: Bonds in a Timeless Journey. CEMEX, Mexico City.

[21] Kruuk, H. (1972) The Spotted Hyena. University of Chicago Press, Chicago.

[22] Akama, J.S. (1998) The Evolution of Wildlife Policies in Kenya. Journal of Third World Studies, 15, 103-117.

[23] Kameri-Mbote, P. (2005) Land Use and Sustainability in Kenya: Towards Innovative Use of Properties Rights in Wildlife Management. International Environmental Law Research Centre.

[24] WRI (World Resource Institute) (2005) Earth Trends Data Tables: Biodiversity and Protected Areas. World Resource Institute, Washington DC. http://www.earthtrends.wri.org/country_profiles/index.php?theme=7

[25] Herremanns, M. (1998) Conservation Status of Birds in Botswana in Relation to Land Use. Biological Conservation, 86, 139-160. http://dx.doi.org/10.1016/S0006-3207(98)00016-0

[26] Caro, T.M. (1999) Densities of Mammals in Partially Protected Areas: The Katavi Ecosystem of Western Tanzania. Journal of Applied Ecology, 36, 205-217. http://dx.doi.org/10.1046/j.1365-2664.1999.00392.x

[27] Loibooki, M., Hofer, H., Campbell, K.L.I. and East, M. (2002) Bush Meat Hunting by Communities Adjacent to the Serengeti National Park, Tanzania: The Importance of Livestock Ownership and Alternative Sources of Protein and Income. Environmental Conservation, 29, 391-298.

[28] Kameri-Mbote, P. (2005) Land Use and Sustainability in Kenya: Towards Innovative Use of Properties Rights in Wildlife Management. International Environmental Law Research Centre (IELRC) Working Paper 2005-4. http://www.ielrc.org/content/w0504.pdf

[29] Pelkey, N.W., Stoner, C.J. and Caro, T.M. (2000) Vegetation in Tanzania: Assessing Long Term Trends and Effects of Protection Using Satellite Imagery. Biological Conservation, 94, 297-309. http://dx.doi.org/10.1016/S0006-3207(99)00195-0

[30] Møller, A.P., Fiedler, W. and Berthold, P., Eds. (2010) Effects of Climate Change on Birds. Oxford University Press, Oxford.

[31] Martin, R. (2011) Book Review: Effects of Climate Change on Birds. Ostrich, 82, 249-250. http://dx.doi.org/10.2989/00306525.2011.628443

[32] Jarvis, M.J.F., Jarvis, C. and Keffen, R.H. (1985) Breeding Seasons and Laying Patterns of the South African Ostrich (Struthio carnelus). IBIS, 1271, 442-449.

[33] NOOA (2008) Droughts: Public Fact Sheet. National Weather Service. http://www.nws.noaa.gov/os/brochures/climate/DroughtPublic2.pdf

[34] PDNA (2011) Kenya Post-Disaster Needs Assessment (PDNA) 2008-2011 Drought. Government of Kenya, Nairobi, Kenya.

[35] Ntiati, P. (2002) Group Ranches Subdivision Study in Loitokitok Division of Kajiado Dis- 
trict. Land Use Change Impacts and Dynamics (LUCID) Working Paper 7, International Livestock Research Institute (ILRI), Nairobi.

[36] Okello, M.M. and D’Amour, D.E. (2008) Agricultural Expansion within Kimana Electric Fences and Implications for Natural Resource Conservation around Amboseli National Park, Kenya. Journal of Arid Environments, 72, 2179-2192.

http://dx.doi.org/10.1016/j.jaridenv.2008.07.008

[37] Reid, R., Gachimbi, L., Worden, J., Wangui, E., Mathai, S., Campbell, D., Maitima, J., Butt, B., Gichohi, H. and Ogol, E. (2004) Linkages between Changes in Land Use, Biodiversity and Land Degradation in the Loitokitok Area of Kenya. Land Use Change Impacts and Dynamics (LUCID) Working Paper Series 49, 1-29.

[38] Dirschl, H., Norton-Griffiths, M. and Wetmore, S.P. (1981) Training Observers for Aerial Surveys of Herbivores. Wildlife Society Bulletin, 9, 108.

[39] Douglas-Hamilton, I., Gachago, S., Litoroh, M. and Mirangi, J. (1994) Tsavo Elephant Count 1994. Report to the Kenya Wildlife Service, Nairobi, Kenya.

[40] Zar, J.H. (1999) Biostatistical Analysis. 4th Edition, Prentice Hall, Upper Saddle River.

[41] Western, D., Groom, R. and Worden, J. (2009) The Impact of Subdivision and Sedentarization of Pastoral Lands on Wildlife in an African Savanna Ecosystem. Biological Conservation, 142, 2538-2546. http://dx.doi.org/10.1016/j.biocon.2009.05.025

[42] Western, D. (1982) Amboseli National Park: Enlisting Landowners to Conserve Migratory Wildlife. Ambio, 11, 302-308.

\section{Submit or recommend next manuscript to SCIRP and we will provide best service} for you:

Accepting pre-submission inquiries through Email, Facebook, LinkedIn, Twitter, etc. A wide selection of journals (inclusive of 9 subjects, more than 200 journals)

Providing 24-hour high-quality service

User-friendly online submission system

Fair and swift peer-review system

Efficient typesetting and proofreading procedure

Display of the result of downloads and visits, as well as the number of cited articles

Maximum dissemination of your research work

Submit your manuscript at: http://papersubmission.scirp.org/

Or contactnr@scirp.org 